\title{
Recycling sterile gold mining waste for use as construction aggregate
}

\author{
Efrain Casadiego-Quintero\# ${ }^{1}$, Carlos Alberto Ríos-Reyes*2, Wilmar Gómez-Ríos\# ${ }^{3}$ \\ \# Research Group in Civil Engineering and Environmental Phenomena, Faculty of Civil Engineering \\ Fundación Universitaria Agraria de Colombia, Bogotá, D.C., Colombia \\ ${ }^{1}$ casadiego.efrain@uniagraria.edu.co \\ ${ }^{3}$ gomez.wilmar@uniararia.edu.co \\ *School from Geología, Universidad Industrial de Santander, Bucaramanga, Colombia \\ ${ }^{2}$ carios@uis.edu.co
}

\begin{abstract}
Gold is found in part by the thousands in rocks, which makes it necessary to mine a large quantity of rock in order to obtain a minimum quantity of gold. This leads to the generation of a significant amount of solid waste product because of the crushing and grinding of the material that generates waste from block size to sandy and fine granulometry. These residues end up as deposits on the surface or slopes that generate the danger of landslides or damage in the soil, another large part of the ground material ends up dumped in rivers and streams, which increases the rate of sedimentation and the deposition of heavy metals. In Colombia, the areas that are dedicated to the exploitation of gold encompass large regions, which generates that a significant amount of water sources are affected, in addition, the mines are in some cases close to the paramos such as the Santurban paramo, an important source of water in the north of Colombia. In the field studies, it was observed that 6 tons of sterile waste is generated per day that meets the standards as a construction aggregate for use in the concrete mix. In the tests carried out it was found that it can be used for structural concrete. Petrographic and chemical analyzes revealed significant silica content from plagioclase, quartz, and micas that make up the sterile residue.
\end{abstract}

Keyword- Waste Minimization, Aggregate Concrete, Sustainability, mining, gold

\section{Introduction}

The world faces the unprecedented challenge of stimulating economic growth while maintaining its sustainability, which leads directly to a transition to energy and resource efficiency technologies based on a circular economy approach [1]. The mineral resources industry remains important for the economy of any country as it continues to play an important role in supplying basic raw materials in different application sectors. Metallic minerals such as gold remain important despite having experienced some decline in production and a drop in demand in the world market [2].

Generally, the extraction of metals generates tons of mining waste raised to the surface, depositing a large amount of rubble tips on previously existing natural soils [3]. Mining and processing are commonly seen as one of the key sources of soil contamination (e.g., [4]; [5]; [6]). The accumulation of waste from abandoned mines, for centuries, poses a serious environmental problem, given its potential toxicity (e.g., [7]; [8]).

\section{Methodology}

The mining waste that was characterized to study the use as aggregate comes from a gold mine in the municipality of Vetas-Santander, where 3 samples were taken to the S-W of the urban area, at kilometer 4 of the road that connects Vetas with California, in X coordinates: 1132426; Y: 1300934 in the La Elsy mine at 3,280 masl (Figure 1), north of the Surata fault, on the Santander Massif south of Berlin. The samples were collected on the Quebrada Jaimes which is located on the right side of the mine downstream and inside the mine. This stream connects with Quebrada La Plata and Quebrada Salado that empties into the Vetas river. The samples from both places were collected from crystalline rocks, described as the Bucaramanga gneiss, plutonic and hydrothermal intrusions.

To propose the proper use of sterile gold mining waste as a construction aggregate, using the regulations required for testing, which may vary in each country. The standard seeks that the aggregate meets the characteristics of resistance, wear, material selection, content of organic matter, sulfates, among others. 
The study of the sterile waste to propose its use as a concrete aggregate was carried out based on compliance with the INVIAS 2012 Standard, which includes: I.N.V.E. 122 (Determination in the laboratory of the water content (Moisture) of soil samples, rock and soil mixtures - aggregate.); I.N.V.E. 213 (Granulometric analysis of coarse and fine aggregates); I.N.V.E 217 (Bulk Density (Unit Weight) and percentage of voids in aggregates in loose and compacted state); I.N.V.E 222 (absorption of fine aggregate); I.N.V.E 402 (Elaboration and curing of concrete specimens in the elaboration for compression and bending tests); and I.N.V.E 410 (Concrete compressive strength).

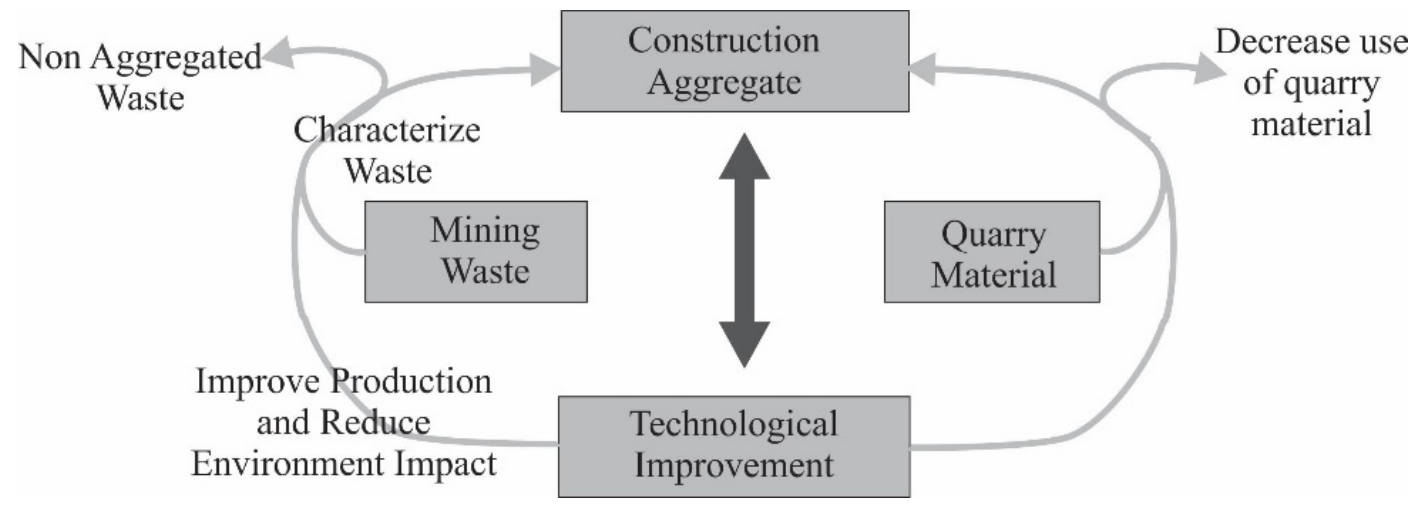

Fig. 1. Conceptual Model of the relationship between sterile waste and construction aggregates.

By means of the preliminary description of the blocks larger than $20 \mathrm{~cm}$ in a macro way with a binocular microscope, the igneous and metamorphic rocks were classified using the Commission on Systematics in Petrology of the IUGS (International Union of Geosciences) according to Le Maitre et al., (2002). The texture of the rock was studied to understand the relationship of the size, shape and arrangement of the minerals, the size of the crystals and their internal structure or factory were also measured.

It was necessary to carry out a field survey to understand the relationship and behavior of the intrusive rock with the nesting rock. This relationship was also reviewed within the mine shaft. The internal architecture was studied where folds and veins were found.

The qualitative analysis was performed by comparing the observed profile with the diffraction profiles reported in the PDF-2 database (2014) of the International Center for Difraction (ICDD). The quantitative analysis of the crystalline phases was carried out by adjusting the observed profile and the diffraction profiles reported in the database using the Rietveld method. The percentages reported correspond to the relationship between the quantified polycrystalline phases without considering the percentage of amorphous material. This mineralogical analysis was carried out by means of X-ray powder diffraction patterns (XRPD). The samples were ground in an agate mortar and then mounted on a polymethylmethacrylate (PMMA) sample holder using the frontal filling technique [10]. The XRPD pattern of the sterile waste was recorded by X-ray diffraction using a BRUKER D8 ADVANCE diffractometer which is used with the Da Vinci geometry methodology and equipped with an X-ray tube (Cu-Ka1 radiation: $\lambda=1.5406 \AA, 40 \mathrm{kV}$ and $30 \mathrm{~mA}$ ), a one-dimensional LynxEye Detector (with $2.93^{\circ}$ opening angle), a $0.6 \mathrm{~mm}$ divergent slot, two $2.5^{\circ}$ axial welds (primary and secondary) and a nickel filter. Data is collected in the $2 \theta$ range of $12-80^{\circ}$, with a step size of $0.01526^{\circ}(2 \theta)$ and a count time of $1 \mathrm{~s} /$ step. Atomic positions, unit cell constants, peak magnification factors, and phase concentrations were refined and calculated using the Rietveld-based MDI program RIQAS.

Sterile waste of various granulometries is produced in the gold mine, due to the mineral extraction process. The thick material obtained from the interior of the mine is made up of angular blocks greater than $200 \mathrm{~mm}$ [11], with irregular edges. The coarse sterile residue is separated from the ore material by means of a $20 \times 20 \mathrm{~cm}$ mesh made with rods of a quarter of an inch in diameter, generally the ore material is constituted by minerals of low mechanical resistance or hardness, friable, which fracture in angular pebbles smaller than $150 \mathrm{~mm}$, later it is passed through a special mat to collect the fines that will be washed in a water tank and the gold is selected by means of the pan; The material that does not remain on the mat is subsequently taken to vibrating tables where the fine-coarse sand is separated from the silt and clay, these last two sizes are taken to a sedimentation plant where a final treatment is carried out to separate part of the Silt and clay, what cannot be separated, is poured into Quebrada Jaimes (Figure 2) 


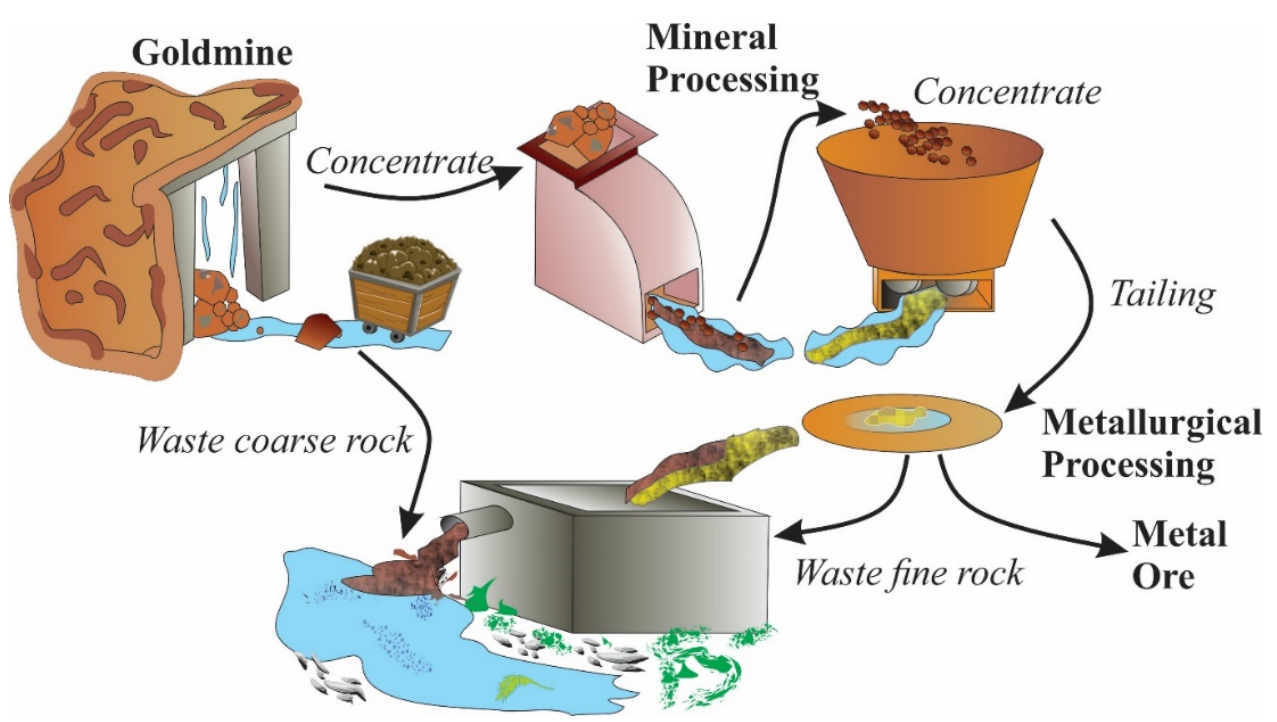

Figure 2. Mining extraction process and production of sterile waste

III. Results and discussion

The igneous body presents a tabular geometry and a discontinuous variable thickness of composition from gneiss to granodiorites, in addition to compositional variations there are changes in the microstructure of the rocks (Figure 3A-C). Lenses and / or pelitic patches 20 to $40 \mathrm{~cm}$ thick are observed inside the mine (Figure 3D), which are exploited for their content of sulfates and other minerals, including gold. The outcrops present small to medium blocks (3 to 8 joints / $\mathrm{m} 3$ ), mainly formed by two families of continuous joints (Figure 3C) with smooth to slightly rough surfaces in the direction of the NW-SE discontinuity plane $\left(30^{\circ}\right.$ to $50^{\circ}$ of course), family 1 presents a slope of $10^{\circ}$ to $20^{\circ}$ and in family 2 slopes between $70^{\circ}$ to $80^{\circ}$ are observed, $80 \%$ are open, $5 \%$ close and $15 \%$ are filled with quartz, the latter most are part of family 2 ; the rock presents a low degree of weathering, being described as healthy rock to something weathered; rock matrix strength is described as hard to extremely hard with a sclerometer single compressive strength of 230-270 MPa. The geomorphology corresponds to steep slopes with residual soils that have generated landslides, mainly in the waste deposit areas (Figure 3E); The materials extracted from the mine are made up of 30 to $40 \mathrm{~cm}$ rock blocks (Figure 3F), which are made up of the Bucaramanga gneiss, which is a massive, tenacious, compact, banded rock (e.g. [12]; [13]). 

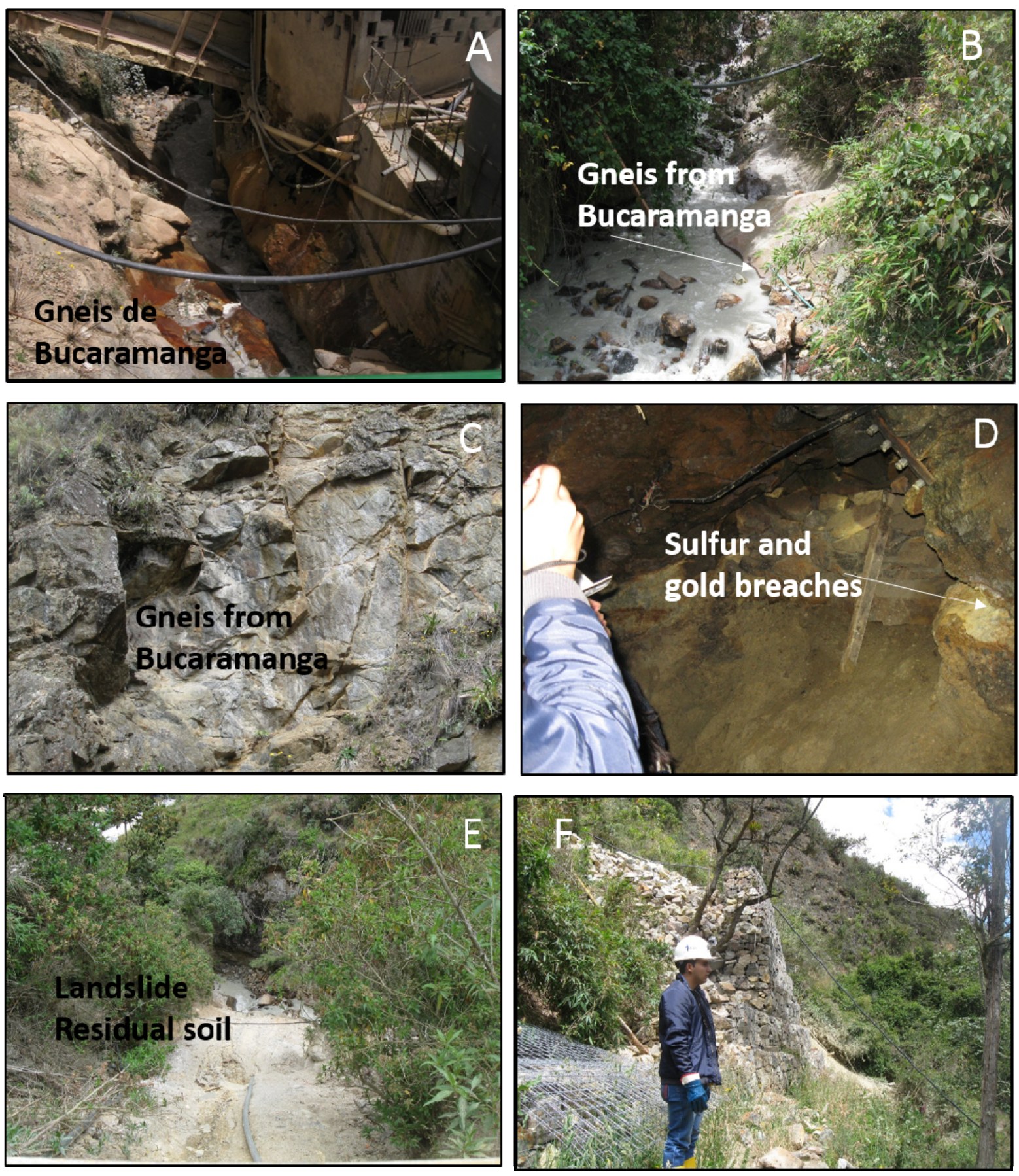

Figure 3. Geological description of the outcrops; A) Bucaramanga gneis formation on Quebrada Jaimes. B) Bucaramanga gneis formation and blocks product of the extraction on the creek. C) Two families of cleats in the outcrops of the gneiss formation. D) Disseminated gold and sulfide lenses injected concordant to gneiss rich in hornblende and granodiorites. E) Sliding in the area of accumulation of extraction product blocks. F) Blocks of gneiss and granodiorites larger than $20 \mathrm{~cm}$ treated as sterile mining waste.

Due to the fact that materials such as concrete or concrete are durable, but can become susceptible to physical-chemical attack that can affect the durability and permeability of the concrete, the petrographic and XRD analysis is carried out to know the composition of the aggregate [14]. Additionally, there may be durability issues that occur in concrete, such as sulfate attack, alkaline aggregate reactions, salt attack, and corrosion of metals. The rocks from gold mining may contain high content of sulfate associated iron sulfides contained in minerals such as pyrite [15], so that the inclusions of iron sulfide in certain proportions in the aggregates established by Construction standards are reactive and seem to generate expansion first in the aggregates and later in the cement mix [16]. According to the characteristics and tests of the aggregates in terms of resistance to disintegration by sulfates, the ASTM C88 (AASHTO T 104), NTC 126 and the I.N.V.E - 220 07 standards should be reviewed. 


\section{A. Petrographic and mineralogical analysis}

Several samples of the three main lithologies of the study area, previously selected in the macroscopic description, were studied for chemical and compositional analysis. The minerals were identified by means of optical microscopy, in which quartz, plagioclase-Na, feldspar K, biotites, amphiboles (hornblende with double exfoliation), pyrite and other iron oxides were found. The scanning electron microscope (SEM) confirms the presence of quartz with irregular contours and some microscrystalline cases, mainly muscovite, biotite and orthoclase; in moderate proportion sodium anorthite, fengite, actinolite and kaolinite; and proportions less than $1 \%$ pyrite and gypsum. The gneiss rich in amphiboles and amphibolites (Figure 4A) present granonematoblastic texture [17], with a neissose structure, with a variation in crystal size of $0.2 \sim 0.6 \mathrm{~mm}$, hornblende and biotites present chloritization.

The granodiorites (Figure 4B-C) present a holocrystalline texture in a dominant (60 to $70 \%$ ) unequal manner, made up of quartz crystals, plagioclase with polysynthetic twinning generated by the $\mathrm{Na} / \mathrm{Ca}$ alternation, with slight hypocrystalline variations (10 to $20 \%$ ), in the parallel nicols (Figure 4C) quartz, potassium feldspar, plagioclase and biotite crystals can be observed. The samples present microfractures with recrystallization and oxidation generated by secondary phases of mineralization (eg. [18]; [19]). Plagioclase shows alteration from the edges of sericitization and biotites present chloritization.
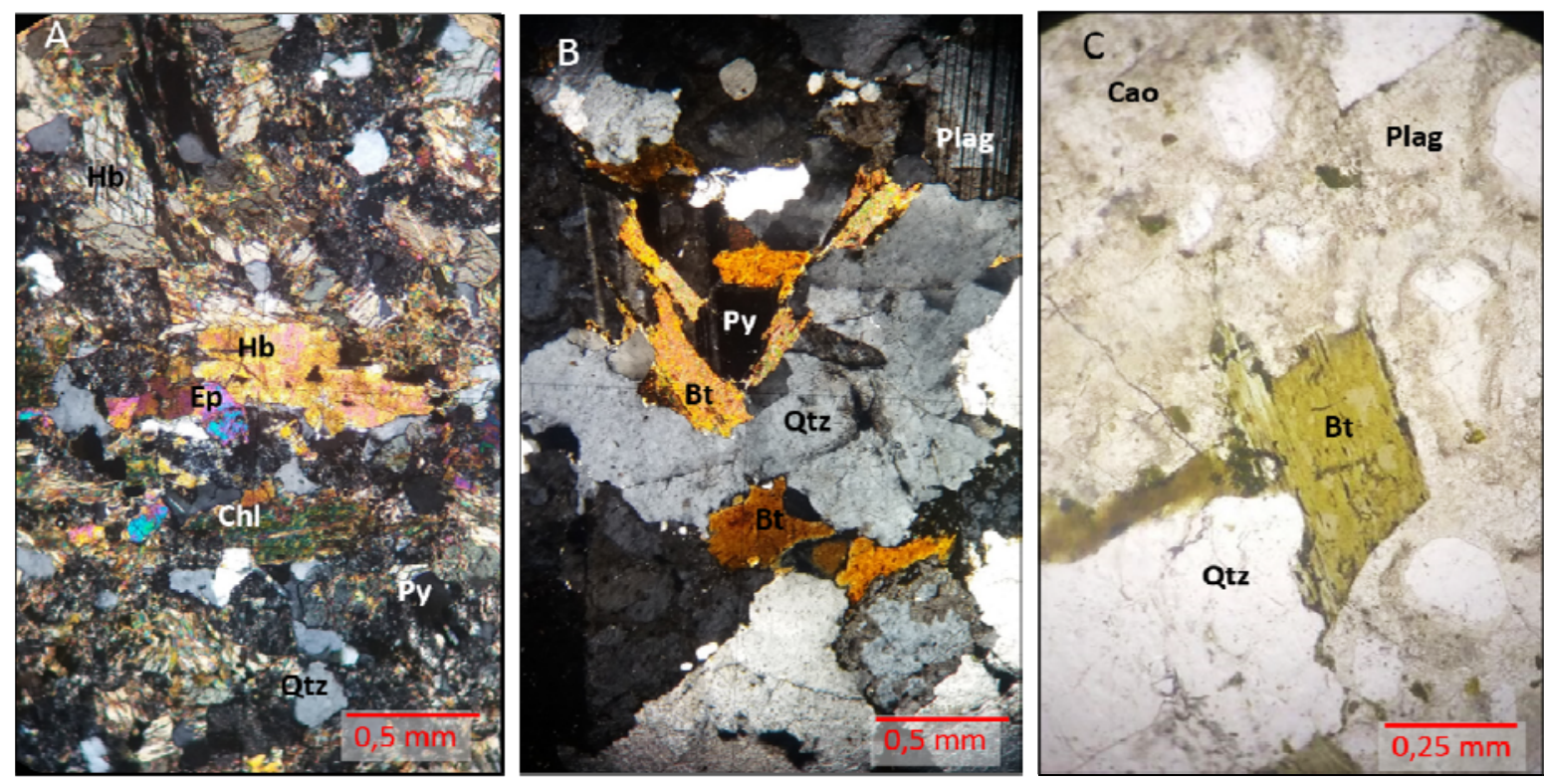

Figure 4. A) Phaneritic crystals composed of quartz, plagioclase, potassium feldspar and amphiboles mainly (Hb) with two directions of exfoliation altering to chlorite (photography in crossed nicols), the crystals are represented by quartz (Qtz), chlorita (Chl), epidote (Ep) and chlorite (Chl). B) Photograph of granodiorite in crossed nicoles, mainly quartz, biotites (Bt) and plagioclase (Plag) with polysynthetic twinning and pyrite in smaller quantity (Py). C) Quartz, biotite, Kaolinite (Cao) and plagioclase in a granite rock (photography in parallel nicoles).

SEM allowed to verify the texture of the mineral phases (Figure 5), define the mineral composition and chemical elements of the filonian filling and of the concrete made with the sterile waste. SEM images of the vein show euhedral and millimeter crystals of pyrite, plagioclase-Ca and quartz, surrounded by calcareous clay product of hydrothermal alteration. The BSED image and the EDS (semi) quantitative spectrum analysis show the content of carbon $(\mathrm{C}=10 \mathrm{wt} \%)$, oxygen $(\mathrm{O}=15 \mathrm{wt} \%),(\mathrm{S}=32 \mathrm{wt} \%)$ and $(\mathrm{Fe}=41 \mathrm{wt} \%)$ in sulfate minerals. 

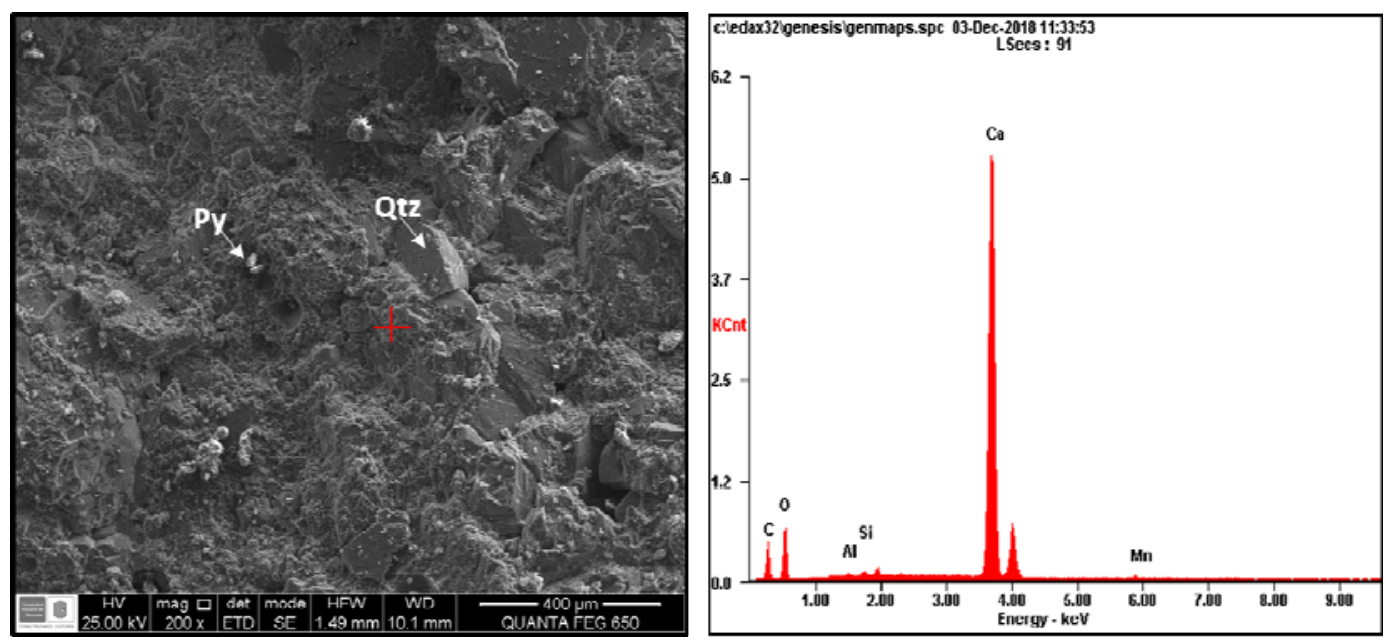

Figure 5. SEM image and EDS spectrum of the concrete sample made with the sterile gold mining waste: The SEM image shows a consistent sample, with pyrite crystals (Py) and quartz (Qtz); granular texture of concrete.

The sterile medium to coarse sand-size residue from Zone 5 was tested for X-ray diffraction (XRD) and it was obtained that the main component is quartz (Qtz), muscovite (Mu) and orthoclase (Or) [20]. See Table 1.

Table 1. Chemical composition of sterile gold mine waste ( $\mathrm{wt} \%)$

\begin{tabular}{lccccccccccc}
\hline Constituent & Qtz & Or & AnSo & Fegt & Act & Cao & Ver & Gy & Py & Flg & Mu \\
\hline Content & 43,6 & 16,4 & 5,7 & 2,4 & 2,3 & 2,1 & 0,5 & 0,5 & 0,5 & 6,9 & 18,9 \\
\hline
\end{tabular}

In Figure 6 the results obtained from the resistance to compression of concrete cylinders are compared. The resistance at 28 days is considered as the maximum compression tolerance that a concrete element can withstand, although concrete continues to increase its compressive strength with the setting time, depending on the mineralogical evolution of type I portland cement in the hydration process, which can reveal the transformation of anhydrous mineral phases of cement into stable hydrated phases [21]. From the compressive strength test, it was analyzed that almost $100 \%$ of the compressive strength occurs at 28 days. The aggregate used from the sterile gold mine waste (MM) follows the same pattern as the other three samples, exceeding $3000 \mathrm{PSI}(21 \mathrm{MPa})$ of load at 28 days and increasing its resistance without stabilizing; sample $\mathrm{C} 1$ is the one with the lowest compressive strength at 28 days. According to the compressive strength tests carried out, this concrete is classified as normal resistance, which complies with the NSR-10 standard - Title C. (C.19.3.1), the compressive strength calculated for day 28 , exceeds the $21 \mathrm{MPa}$ obtaining a structural concrete.

An easy way to comply with the conference paper formatting requirements is to use this document as a template and simply type your text into it.

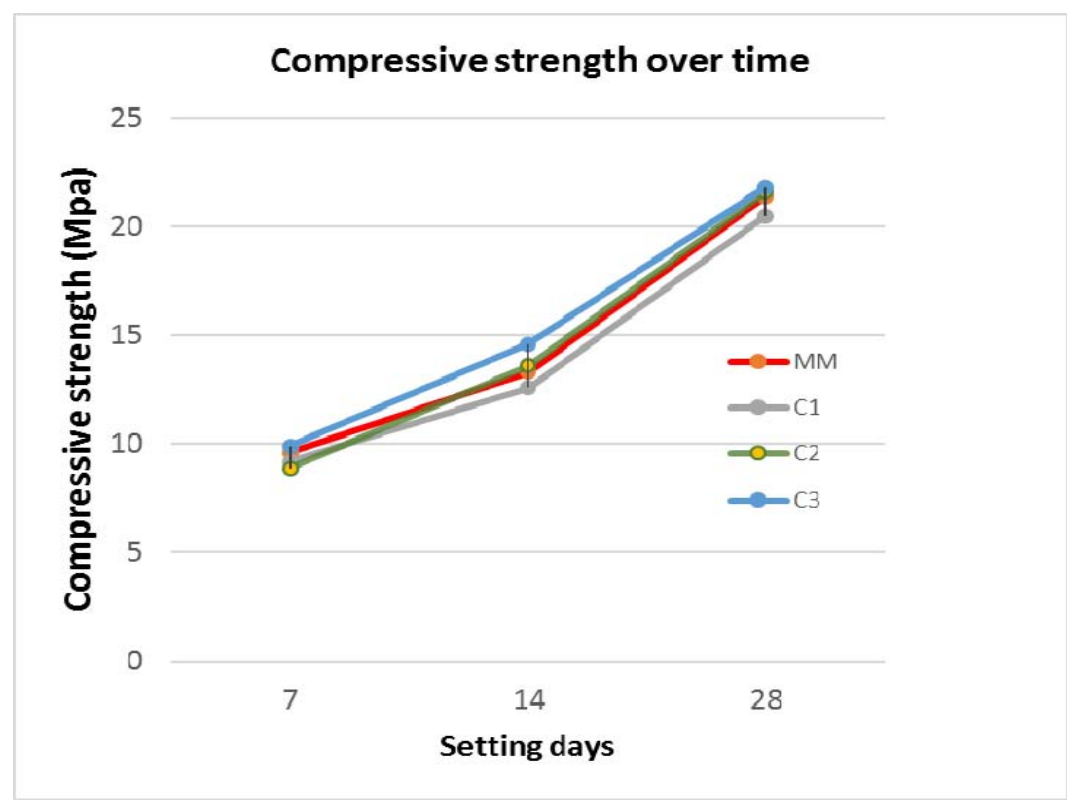

Figure 6. Results of compressive strength over time of concrete cylinders. 
The evaluation of the reuse of sterile gold mining waste from Vetas-Santander as aggregate for concrete, has been carried out using fine to medium sands with high silica content. The results obtained show that the use of the waste is possible because it complies with the INVIAS 2012 Standard, its use could generate economic gains, rural development because in many cases there are no nearby quarries that generate good quality material for concrete or roads, in addition to the possibility of reducing the dumping of these wastes in rivers and streams that increase sedimentation and the content of metals in the water.

On the other hand, sterile mining waste can contain high sulfide concentration and its amount can be affected by minerals such as "pyrite". In the tests carried out on sterile sand-size waste from Zone 5, the content of pyrite (FeS2) is less than $5 \%$ and in XRD less than $1 \%$, which gives a low content of sulfides.

In the study result of the sterile waste from Zone 5, it was possible to verify that because the material comes from inside a mine, it does not contain organic matter, which can occur with quarry material that comes from mines to open sky; In addition, in the case of La Elsy Mine, a system is used that facilitates the separation of sterile clay and sand-size waste at the end of the selection cycle. The chemical composition of the waste is mainly siliceous, reducing the possibility of alterations that generate clays and secondary porosity due to dissolution or microfractures.

\section{Conclusion}

According to the results obtained, the textures of the samples were analyzed to establish the relationship of the size, shape and arrangement of the minerals. Sclerometer tests describe gneiss blocks for their simple compressive strength of $180 \mathrm{Mpa}$. Performing the compositional analysis of the sterile waste and its aggregates based on the mineralogical and petrographic study, it is established that these aggregates comply with the resistance characteristics and the geotechnical specifications for the design of hydraulic concrete pavements and hydraulic concrete bases.

The reuse of sterile waste, a product of mining, is presented as an alternative to construction materials that can be used in rural development. This research was carried out in the gold mine in the municipality of Vetas Santander, in which residues of various granulometries are produced, however, the material that is not possible to separate, is dumped on the Quebrada Jaimes, causing the scarcity of the resource water, as well as water pollution.

\section{Acknowledgment}

The authors would like to thank the support provided by the Fundación Universitaria Agraria de Colombia and the Universidad Industrial de Santander, who contributed knowledge and experience that helped to carry out this research.

\section{References}

[1] Jagodzińska, K., Nuran-Zaini, I., Svanberg, R., Yang, W. \& Göran-Jönsson, P. (2020). Pyrolysis of excavated waste from landfill mining: Characterisation of the process products Journal of Cleaner Production In press, journal pre-proof Available

[2] Mohd-Kusin, F., Che-Awang, N. H., Syed-Hasan, S. N. M., Abdul-Rahim, H. A. \& Woong-Kim, K. (2019). Geo-ecological evaluation of mineral, major and trace elemental composition in waste rocks, soils and sediments of a gold mining area and potential associated risks CATENA. Vol. 183.

[3] Bragina, P.S. \& Gerasimova, M.I. (2014). Pedogenic processes on mining dumps (a case study of southern Kemerovo oblast). Geogr. Nat. Resour, 35 (1). pp. 35-40.

[4] Mishra, V.K., Upadhyaya, A.R., Pandey, S.K. \& Tripathi. B.D. (2008). Heavy metal pollution induced due to coal mining effluent on surrounding aquatic ecosystem and its management through naturally occurring aquatic macrophytes. Bioresour. Technol., Vol. 99. pp. 930-936.

[5] Khoroshavin, V.Y. \& Moiseenko. T.I. (2014). Petroleum hydrocarbon runoff in rivers flowing from oil-and-gas-producing regions in Northwestern Siberia. Water Res., 41 (5). pp. 532-542.

[6] Beloglazov, I.I., Bazhin, V.Y. \& Zyryanova. O.V. (2016). Upgrading of the process of technological pulp separation in modern pressure filters. Non-Ferrous Met., Vol. 1. pp. 38-40.

[7] Adabanija, M.A. \& Oladunjoye. M.A. (2014). Geoenvironmental assessment of abandoned mines and quarries in South-western Nigeria. J. Geochem. Explor., Vol. 145. pp. 148-168.

[8] Kossoff, D., Dubbin, W.E., Alfredsson, M., Edwards, S.J., Macklin, M.G. \& Hudson-Edwards, K.A. (2014) Mine tailings dams: characteristics, failure, environmental impacts, and remediation. Appl. Geochem., Vol. 51. pp. 229-245.

[9] Le Maitre, R., Streckeisen, A., Zanettin, B., Le Bas, M., Bonin, B., Bateman, P., Bellieni, G., Dudek, A., Efremova, S., Keller, J., et al. [2002], Igneous rocks: A classification and glossary of terms: Recommendations of the international union of geological sciences subcommission on the systematics of igneous rocks.

[10] Casadiego-Quintero, E., Gutiérrez-Bayona, A. G., Herrera-Lopez, M. Ángel, \& Páez-Rojas, M. L. (2017). Manejo estratégico de la producción de residuos estériles de minería sustentable, utilizando prácticas mineras eco-eficientes en Colombia. Revista De Investigación Agraria Y Ambiental, 8(2). pp. 107 - 118. https://doi.org/10.22490/21456453.2035

[11] Tucker, M. E. (2011). Sedimentary Rocks in the Field: A Practical Guide. p. 7.

[12] García-Ramírez, C. A. \& Uribe-Portilla, E. (2006). Caracterización geológica y mineralógica del yacimiento la tosca (Vetas, Santander, Colombia): implicaciones para el procesamiento mineral de las menas auroargentíferas. Boletín de Geología, 28(2):63-76.

[13] Casadiego-Quintero, E. \& Florez, M. (2017). Desarrollo rural educación y posconflicto por medio del aprendizaje basado en proyectos. Reflexiones Pedagógicas y didácticas a partir de la enseñanza de la ingeniería, pp. 64-79.

[14] Mindess, S. (2019). 6-Resistance of Concrete to Destructive Agencies, Editor(s): Peter C. Hewlett. Lea's Chemistry of Cement and Concrete (5th Edition). P. 251-283, ISBN 978-0-7506-6256-7. https://doi.org/10.1016/B978-0-08-100773-0.00006-X 
[15] Schmidt, T., Leemann, A., Gallucci, E., and Scrivener, K. (2011). Physical and microstructural aspects of iron sulfide degradation in concrete. Cement and Concrete Research, 41(3). pp. 263-269.

[16] Har, N., Lăzărean, A., Iliescu, M., Ciont, N., and Abrudan, I. F. (2019). Degradation processes of iron-sulfides and calcite containing aggregates from asphaltic mixtures. Construction and Building Materials, Vol. 212. pp. 745-754.

[17] Mackenzie, W. S., Guilford, C. \& Yardley. B. W. (1996) Atlas de Rocas Metamorficas y Sus Texturas. Masson, S.A. Madrid. pp. 5981.

[18] Zuluaga, C.A., Amaya, S., Urueña, C., Bernet, M., 2017. Migmatization and low-pressure overprinting metamorphism as record of two pre-Cretaceous tectonic episodes in the Santander Massif of the Andean basement in northern Colombia (NW South America). Lithos. Vol. 274-275. pp. 123-146. http://dx.doi.org/10.1016/j.lithos.2016.12.036

[19] Ramos, C. G., Querol, X., Dalmora, A. C., De Jesus Pires, K. C., Schneider, I. A. H., Oliveira, L. F. S., and Kautzmann, R. M. (2017). Evaluation of the potential of volcanic rock waste from southern brazil as a natural soil fertilizer. Journal of Cleaner Production. Vol. 142. pp. 2700-2706.

[20] Li, J., Chen, Z., Shen, B., Xu, Z., and Zhang, Y. (2017). The extraction of valuable metals and phase transformation and formation mechanism in roasting-water leaching process of laterite with ammonium sulfate. Journal of Cleaner Production. Vol. 140. pp.11481155. https://doi.org/10.1016/j.jclepro.2016.10.050

[21] González, A., Villa, E. A., Ríos-Reyes, C. A., 2019. Assessment of Amphibolite and Pegmatite Aggregates for the Manufacture of Concrete. Revista Colombiana de Materiales. Vol. 14. pp. 17-39. https://doi.org/10.1016/j.jclepro.2016.10.050

\section{AUTHOR PROFILE}

Efrain Casadiego Quintero Geologist from the Universidad Industrial de Santander, Bucaramanga Colombia (2008), Master of Science in Geology from the Universidad Industrial de Santander, Bucaramanga (2014). He is currently a full-time professor at the Faculty of Civil Engineering, Coordinator of the Research Seedbed in Civil Engineering and Environmental Phenomena (SEMIICFA) of the Fundación Universitaria Agraría de Colombia and Manager of the Project Use of non-conventional materials for construction

Carlos Alberto Ríos Reyes Geologist from the Universidad Industrial de Santander, Bucaramanga Colombia (1989), Specialist in University Teaching from the Universidad Industrial de Santander, Bucaramanga - Colombia (1995), Master of Science in Geology from Shimane University, Matsue - Japan (1999) and Doctor of Philosophy from University of Wolverhampton, Wolverhampton - United Kingdom (2008). He is currently a full-time full-time professor at the School of Geology, member of the Basic and Applied Geology Research Group (GIGBA) of the Industrial University of Santander and Director of the Microscopy Laboratory of the Industrial University of Santander, Guatiguará Technology Park (PTG).

Wilmar Jair Gómez Ríos Civil Engineer from the Universidad Nacional de Colombia. Bogota - Colombia. Master in Engineering - Hydraulic Resources Universidad Nacional de Colombia. Bogota. Hydraulic Engineer with analytical capacity to model and size sanitary infrastructure systems as well as carry out consulting projects in hydraulic and hydrological studies and designs. He is currently a full-time teacher at the Fundación Universitaria Agraria de Colombia. 